УДК 619:618.312.2-002:637.438

doi:10.36359/scivp.2019-20-2.42

\title{
ЕФЕКТИВНІСТЬ ПРЕПАРАТУ «ВІТОСЕПТ» ЗА ПЕРЕДІНКУБАЦИЙНОЇ ОБРОБКИ ЯЄЦЬ
}

\author{
М. П. Солтис, аспірант ${ }^{9}$
}
Львівський національний університет ветеринарної медицини та біотехнологій імені С. 3. Гжицького, вул. Пекарська, 50, м. Львів, 79010, Україна

У статті наведені результати застосування препарату «Вітосепт», діючою речовиною якого є натрію гіпохлорит, для передінкубачійної обробки яєць.

У прочесі проведеного аналізу на поверхні яєць встановлено наявність бактерій, дріжджів, пліснявих грибів, у тому числі й гнильних мікроорганізмів. Виявлено та ідентифіковано різні види мікроорганізмів, серед яких основними були Рsеидотопаs aeruginosa, Micrococcus halobius, Staphylococcus aureus, Escherichia coli, Salmonella typhimurium, Salmonella pullorum, Proteus vulgaris, Aeromonas spр. Залежно від ступеня забруднення мікробна контамінація поверхні яєць коливалась у межах від 2 до 5 млн. мікробних тіл у розрахунку на одне яйще. Найменше забруднення яєць в інкубаційній $і$ вивідній шафах спостерігалося на рівні верхнього ярусу лотків, найбільше - нижнього.

Показники виводимості яєць при застосуванні різних концентрацій препарату «Bітосепт» (P<0,01-0,05\%) були вірогідно вищі, при иььму збереженість курчат до 60добового віку була на 10 \% більшою, аніж у варіанті, де застосовувалась обробка яєиь класичним методом парами формальдегіду. За такої кількості активного гіпохлориту натрію в препараті відсоток недорозвинених плодів (завмерлі, задохлики, слабкі та каліки) теж був найнижчим, порівняно із партією яєць, оброблених класичним способом, иляхом примінення формальдегіду, чи иим же препаратом, але з дещо нижчою дозою активно діючої речовини. Кращий дезінфікуючий ефект препарат «Вітосепт» проявляє за наявності в ньому натрію гіпохлориту в кількості 500 мг/л. За передінкубаційної обробки яєць курей препаратом «Bітосепт» виводимість курчат, порівняно з партією яєиь, оброблених формаліном зростає до 97,5\%, а збереженість - до 95,7\%.

Ключові слова: НАТРІЮ ГІПОХЛОРИТ, ПРЕПАРАТ «ВІТОСЕПТ», ЯЙЦЯ КУРЕЙ, ВИВОДИМІСТЬ, ЗБЕРЕЖЕНІСТЬ.

Птахівництво - динамічна галузь, що має інтенсивні методи виробництва, високий рівень механізації та найбільший потенціал щодо швидкого насичення ринку України високоякісною продукцією. Виробництво продуктів птахівництва є однією з найважливіших складових світового та вітчизняного агропромислового комплексу і його важко переоцінити 3 позиції внеску у продовольчу безпеку [1].

Від якості інкубаційних яєць залежить рівень важливих біоекономічних показників вивід молодняку, життєздатність і продуктивність птиці. У процесі інкубації яєць сільськогосподарської птиці є багато специфічних особливостей, які можна використовувати для управління процесом розвитку птиці [2].

Якість шкаралупи має велике значення, оскільки від неї залежать бій яєць (зовнішня і внутрішня насічка, витікання), здатність до тривалого зберігання, мікробна безпека i виводимість курчат. Встановлено, що за низької якості шкаралупи змінюється іiї структура, а

${ }^{9}$ Науковий керівник - В. М. Гунчак, доктор ветеринарних наук, професор 
отже збільшується проникнення через неї бактерій. Під час інкубації яєць із тонкою шкаралупою зменшується вивід молодняку, бо в таких яйцях або більше пор - і ембріони підсихають у процесі інкубації, або їх мало, i ембріони захлинаються надлишком навколоплідної рідини, яка випаровується повільно. Відомо, що від якості яєць залежать результати їх інкубації. При цьому вона вимірюється не тільки вмістом в них поживних та біологічно активних речовин, але і ветеринарно-санітарними умовами отримання і збереження яєць як до, так і в період їх інкубації. Основна мета інкубації яєць полягає в одержанні якомога здоровішого та кондиційного молодняку, що залежить від багатьох чинників, і зокрема від рівня мікробного забруднення яєць [3, 4].

Для передінкубаційної обробки яєць застосовують різні дезінфектанти. Одним 3 поширених таких препаратів $\epsilon$ формалін, однак його використання становить небезпеку як для персоналу підприємств, так і для кінцевого споживача готової продукції. Інколи для обробки яєць використовують озон, який ефективний тільки при дезінфекції чистих яєць, оскільки він не спроможний проникати через шар забруднення на шкаралупі $[5,6]$.

Тому пошук препаратів, які 6 з одного боку проявляли ефективну протимікробну дію, a 3 іншого - не мали негативного впливу на довкілля та якість продукції $\epsilon$ особливо актуальним. 3 цією метою нами в експерименті з'ясовано дезінфікуючу дію новоствореного препарату «Вітосепт» за обробки ним інкубаційних яєць. «Вітосепт» $є$ екологічно чистим препаратом, у якому діючою речовиною виступає натрію гіпохлорит, отриманий електрохімічним шляхом. Розчини натрію гіпохлориту, в якості дезінфектанту, широко використовуються в багатьох країнах, зокрема Японії, США, Великобританії, Німеччині, Росії тощо. Їх випускають в розчинах різної концентрації з використанням стабілізаторів. Саме його широкий спектр протимікробної дії, бактерицидні, спороцидні та протигрибкові властивості відкривають практично безмежні можливості для застосування у птахівництві, як ефективного дезінфікуючого засобу, що не володіє шкідливою дією на навколишнє середовище, не викликає ускладнень і побічних явищ, у нього відсутні мутагенні та канцерогенні властивості [7-9]. Однак, ефективність цього препарату, зокрема для дезінфекції інкубаторних шаф та яєць вимагає більш детальних досліджень, що і стало метою нашої роботи.

Матеріали і методи. Яйця контрольної та дослідної партій інкубували в інкубаторі «Насєдка», що знаходився у віварії ДНДКІ ветеринарних препаратів та кормових добавок Першу партію яєць, яка слугувала контролем, обробляли парами формальдегіду, а другу і третю препаратом «Вітосепт», концентрація якого становила 500 мг/л та 300 мг/л. Впродовж інкубації спостерігали за розвитком ембріонів, враховували ембріональну патологію. Після інкубації рахували виводимість і збереженість молодняка до 60-добового віку. Овоскопію проводили на 5, 11 та 19-ту доби інкубації. За допомогою розтину встановлювали причини ембріональної патології. Після виводу молодняку курей підраховували відсоток виводимості яєць.

Бактеріологічний контроль якості дезінфекції шафи та поверхні яєць проводили на 1315 доби інкубації. Для визначення ступеня мікробної забрудненості поверхонь робили змиви (10х10 см) стерильним тампоном з фізіологічним розчином із внутрішніх частин інкубаційних шаф (двері, верхня, нижня, права та ліва стінки). Змиви 3 поверхні шкаралупи яєць, що перебували у лотках кожної зони шафи (верх, середина, низ, визначали середній показник 35 проб), брали на тупому, гострому кінцях і боковій частині за діаметром. Проби висівали на поживні й елективні середовища з метою визначення кількості колонієутворюючих організмів (КУО). Видовий склад мікрофлори, виділеної на рідких та щільних поживних середовищах, ідентифікували за морфологічними, культуральними та біохімічними властивостями, згідно 3 визначником бактерій Берджі (1997).

Результати й обговорення. Мікробіологічними дослідженнями рівня контамінації інкубаторів і поверхні шкаралупи яєць встановлено, що на візуально чистій поверхні шкаралупи яєць перебуває від 1 до 13 тис., на середньо забрудненій - від 300 до 950 тис., за 
сильного забруднення - від 3,5 до 24 млн мікробних тіл. Через 1 годину після знесення кількість мікробних тіл на візуально чистій поверхні шкаралупи яєць збільшувалась до 10 тис., вже через 2 години - до 450 тис. (табл.1)

Таблиця I

Контамінація інкубаторів та поверхні шкаралупи яєць, $(\mathrm{M} \pm \mathrm{m})$

\begin{tabular}{|c|l|c|}
\hline \multicolumn{2}{|c|}{ Мікроорганізми } & Кількість, м.т./см ${ }^{2}$ \\
\hline 1 & Pseudomonas aeruginosa & $0,2 \times 10^{5} \pm 0,2 \times 10^{3}$ \\
\hline 2 & Micrococcus halobius & $0,5 \times 10^{5} \pm 0,1 \times 10^{5}$ \\
\hline 3 & Staphylococcus aureus & $1,2 \times 10^{5} \pm 0,2 \times 10^{5}$ \\
\hline 4 & Escherichia coli & $1,7 \times 10^{5} \pm 0,7 \times 10^{5}$ \\
\hline 5 & Salmonella typhimurium & $0,3 \times 10^{4} \pm 0,4 \times 10^{3}$ \\
\hline 6 & Salmonella pullorum & $1,7 \times 10^{3} \pm 0,7 \times 10^{3}$ \\
\hline 7 & Proteus vulgaris & $1,5 \times 10^{4} \pm 0,4 \times 10^{4}$ \\
\hline 8 & Aeromonas spp. & $1,3 \times 10^{3} \pm 0,3 \times 10^{3}$ \\
\hline
\end{tabular}

Отже, у процесі аналізу на поверхні яєць встановлено наявність бактерій, дріжджів, пліснявих грибів, у тому числі й гнильних мікроорганізмів. Згідно з даними табл. 1 було виявлено та ідентифіковано таку мікрофлору: Pseudomonas aeruginosa, Micrococcus halobius, Staphylococcus aureus, Escherichia coli, Salmonella typhimurium, Salmonella pullorum, Proteus vulgaris, Aeromonas spp. Залежно від ступеня забруднення, мікробна контамінація поверхні яєць коливалась у межах від 2 до 5 млн. мікробних тіл у розрахунку на одне яйце. Найменше забруднення яєць в інкубаційній і вивідній шафах спостерігали на рівні верхнього ярусу лотків, найбільше - нижнього.

Результати інкубації курячих яєць, оброблених перед інкубацією різними методами дезінфекції, наведені у табл. 2

Табличя 2

Результати інкубації яєць, оброблених різними методами дезінфекції в умовах віварію

\begin{tabular}{|c|c|c|c|c|}
\hline \multirow{2}{*}{ Показники } & \multirow{2}{*}{$\begin{array}{l}\text { Одиниці } \\
\text { виміру }\end{array}$} & \multicolumn{3}{|c|}{ Методи обробки } \\
\hline & & Формальдегід & Вітосепт 300 мг/л & Вітосепт 500 мг/л \\
\hline Закладено & шт. & 1500 & 1500 & 1500 \\
\hline \multirow{2}{*}{ Незапліднені яйця } & ШТ. & 189 & 67 & 45 \\
\hline & $\%$ & 12,6 & 4,5 & 3,0 \\
\hline \multirow{2}{*}{ «Кров’яне кільце» } & Шт. & 126 & 39 & 5 \\
\hline & $\%$ & 8,4 & 2,8 & 1,1 \\
\hline \multirow{2}{*}{ Завмерлі } & Шт. & 42 & 7 & 4 \\
\hline & $\%$ & 2,8 & 0,5 & 0,9 \\
\hline \multirow{2}{*}{ Задохлики } & Шт. & 58 & 18 & 3 \\
\hline & $\%$ & 3,9 & 1,2 & 0,6 \\
\hline \multirow{2}{*}{ Слабкі та каліки } & Шт. & 25 & 3 & 1 \\
\hline & $\%$ & 1,7 & 0,2 & 0,3 \\
\hline \multirow{2}{*}{ Вивід курчат } & шт. & 1060 & 1366 & 1442 \\
\hline & $\%$ & 70,6 & 91,1 & 96,1 \\
\hline
\end{tabular}

Як видно з табл. 2, показники виводимості яєць, при застосуванні препарату «Вітосепт» в різних концентраціях вірогідно вищі, ніж у варіанті, де застосовувалась обробка класичним методом - парами формальдегіду.

При цьому відзначено, що найменшим відсоток незапліднених яєць був у партії яєць, оброблених вітосептом у дозі 500 мг/л. За такої кількості активного натрію гіпохлориту в препараті відсоток недорозвинених плодів (завмерлі, задохлики, слабкі та каліки) теж був найнижчим, порівняно із партією яєць, оброблених класичним способом, шляхом 
застосування формальдегіду, чи цим же препаратом, але з дещо нижчою кількістю активно діючої речовини.

Препарат «Вітосепт» проявляє дезінфікуючі, антисептичні, протимікробні властивості та не проявляє мутагенної чи канцерогенної дії. Очевидно, що антибактеріальна дія препарату пов'язана із здатністю натрію гіпохлориту, який входить до складу «Вітосепту», вивільняти атомарний Оксиген, що є сильним окисником. При цьому, він руйнує молекули будь-яких органічних субстратів, проявляє бактерицидний ефект, пов'язаний із руйнуванням клітинної стінки та виходом вмісту цитоплазми. Активний щодо грампозитивних та грамнегативних мікроорганізмів (в т. ч. за серації синьогнійної та кишкової паличок), більшості патогенних грибів (зокрема роду Candida), найпростіших, вірусів тощо.

Показники виводимості та збереженості курчат, за умови застосування різних методів передінкубаційної обробки яєць у виробничих умовах, наведено в табл. 3.

Таблиия 3

Показники виводимості та збереженості курчат, за умови застосування різних методах передінкубаційної обробки яєць у виробничних умовах

\begin{tabular}{|c|c|c|c|c|}
\hline \multirow{2}{*}{ Методи обробки } & \multicolumn{2}{|c|}{ Виводимість, гол./\% } & \multicolumn{2}{|c|}{ Збереженість до 60 доби } \\
\cline { 2 - 5 } & всього & $\%$ & Всього & $\%$ \\
\hline Формальдегід (контроль) & 33660 & 74,8 & 28872 & 85,2 \\
\hline «Вітосепт»500 мг/л & 32940 & $97,5 *$ & 31536 & $95,7 *$ \\
\hline «Вітосепт» 300 мг/л & 35595 & $94,3 *$ & 34136 & $95,7 *$ \\
\hline
\end{tabular}

Примітка: *_ $>$ <0,01, ** - 0,05 по відношенні до формальдегіду

Встановлено, що первинний (протягом приблизно доби після обробки) санаційний ефект випробуваних дезінфектантів у кількісному аспекті майже не відрізнявся. Однак, під час подальшої інкубації оброблених яєць були виявлені значні розбіжності в дослідних партіях, як за показниками загальної контамінації поверхні яєць патогенною мікрофлорою, так і за біологічними показниками (виводимість та збереженість курчат). Так, виводимість яєць при застосуванні препарату «Вітосепт» в дозах 500 мг / л (97,5 \%) і 300 мг / л (94,3\%) була вірогідно вищою, при цьому збереженість курчат до 60-добового віку теж була на 10 \% більшою, ніж у варіанті, де застосовувалась обробка класичним методом парами формальдегіду $(74,8$ \%).

Отже, діюча речовина препарату «Вітосепт» - натрію гіпохлорит, $\epsilon$ природньою екологічно чистою сполукою, не володіє шкідливою дією на навколишнє середовище, не викликає ускладнень і побічних явищ. На думку багатьох науковців в низьких концентраціях $\epsilon$ імуномодулятором, покращує газообмін та підвищує виводимість та збереженість молодняку птиці до 60-ої доби життя.

\section{В И С Н О В К И}

1. Кращий дезінфікуючий ефект препарат «Вітосепт» проявляє за наявності в ньому натрію гіпохлориту в кількості 500 мг/л.

2. За передінкубаційної обробки яєць курей препаратом «Вітосепт» виводимість курчат, порівняно з партією яєць, оброблених формаліном, зростає до 97,5 \%, а збереженість - до $95,7 \%$.

Перспективи досліджень. Метою наших подальших досліджень буде з'ясування антисептичного впливу натрію гіпохлориту, отриманого електрохімічним методом, за ранової інфекції у собак. 


\title{
THE EFFECTIVENESS OF THE DRUG «VITOSEPT» FOR THE PRE-INCUBATION TREATMENT OF EGGS
}

\author{
M. P. Soltys \\ Lviv National University of Veterinary Medicine and Biotechnologies named after S. Z. Gzhytskyi \\ 50, Pekarska str., Lviv, 79010, Ukraine
}

\section{S U M M A R Y}

The article presents the results of the application of the drug "Vitosept", the active substance of which is sodium hypochlorite, for the pre-incubation treatment of eggs.

In the course of the analysis, the presence of bacteria, yeasts, molds including fungal microorganisms has been identified on the surface of the eggs. Microorganisms were identified and identified, among which the most common were Pseudomonas aeruginosa, Micrococcus halobius, Staphylococcus aureus, Escherichia coli, Salmonella typhimurium, Salmonella pullorum, Proteus vulgaris, Aeromonas spp. Depending on the degree of contamination, the microbial contamination of the egg surface ranged from 2 to 5 million microbial bodies per egg. The least contamination of eggs in the incubation and evisceration cabinets was observed at the level of the upper tier of the trays, most notably the lower ones.

Indicators of evapotranspiration of eggs at application of different concentrations of the drug "Vitosept" ( $\mathrm{P}<0,01-0,05 \%$ ) were probably higher, while preservation of chickens up to 60 days of age was also $10 \%$ higher, even in the variant where it was used treatment of eggs by the classical method of formaldehyde pairs. In the amount of active sodium hypochlorite in the preparation, the percentage of underdeveloped fruits (frozen, dyspnea, weak and crippled) was also the lowest, compared to a batch of eggs, treated in the classical way, by the addition of formaldehyde or the same preparation, but with a slightly lower amount of active substance. The best disinfectant effect of the drug "Vitosept" is shown in the presence of sodium hypochlorite in the amount of $500 \mathrm{mg} /$ liter. In the pre-incubation treatment of eggs of chickens with drug "Vitosept", the withdrawable of chickens, compared with the proportion of eggs, treated with formalin increases to $97.5 \%$, and preservation up to $95.7 \%$.

Keywords: SODIUM HYPOCHLORITE, DRUG "VITOSEPT", EGGS OF CHICKENS, WITHDRAWABLE OF CHICKENS, PRESERVATION.

\section{ЭФФЕКТИВНОСТЬ ПРЕПАРАТА «ВИТОСЕПТ» ПРИ ПЕРЕДИНКУБАЦИОННОЙ ОБРАБОТКЕ ЯИЦ}

\section{М. П. Солтыс}

Львовский национальный университет ветеринарной медицины и биотехнологий имени С. 3. Гжицкого ул. Пекарская, 50, г. Львов, 79010, Украина

\section{А Н Н О Т А ЦИ Я}

В статье приведены результаты применения препарата «Витосепт», действующим веществом которого является натрия гипохлорит, для перединкубационной обработки яиц.

В процессе проведенного анализа на поверхности яиц установлено наличие бактерий, дрожжей, плесневых грибов, в том числе и гнилостных микроорганизмов. Обнаружено и идентифицировано различные виды микроорганизмов, среди которых основными были Pseudomonas aeruginosa, Micrococcus halobius, Staphylococcus aureus, Escherichia coli, Salmonella typhimurium, Salmonella pullorum, Proteus vulgaris, Aeromonas spp. В зависимости 
от степени загрязнения микробная контаминация поверхности яиц колебалась в пределах от 2 до 5 млн. микробных тел в расчете на одно яйцо. Малейшее загрязнение яиц в инкубационном и выводном шкафах наблюдалось на уровне верхнего яруса лотков, больше всего - нижнего.

Показатели виводимости яиц при применении различных концентраций препарата «Витосепт» (P <0,01-0,05 \%) были достоверно высшие, при этом сохранность цыплят до 60суточного возраста была на 10 \% больше, чем в варианте, где применялась обработка яиц классическим методом парами формальдегида. При таком количестве активного натрия гипохлорита в препарате процент недоразвитых плодов (замершие, задохлики, слабые и калеки) тоже был самым низким по сравнению с партией яиц, обработанных классическим способом, путем применения формальдегида, или этим же препаратом, но несколько ниже дозой активно действующего вещества. Лучший дезинфицирующий эффект препарат «Витосепт» проявляет при наличии в нем натрия гипохлорита в количестве 500 мг / л.

При перединкубационной обработке яиц кур препаратом «Витосепт» выводимость цыплят, по сравнению с партией яиц, обработанных формалином, возрастает до 97,5 \%, а сохранность - до 95,7\%.

Ключевые слова: НАТРИЯ ГИПОХЛОРИТ, ПРЕПАРАТ «ВИТОСЕПТ», ЯЙЦА КУР, ВЫВОДИМОСТЬ, СОХРАННОСТЬ.

\section{Л I T E P A T Y P A}

1. Ярошенко Ф. Сучасні світові тенденції розвитку птахівництва / Ф. Ярошенко // К.: Новий друк. 2003. 335 с.

2. Птахівництво і технологія виробництва яєць та м’яса птиці. / В. І. Бесулін, В. І. Гужва, С. М. Куцак [та інші]. За ред. В. І. Бесуліна. Біла Церква, 2003. - 448 с.

3. Саприкин Л. Прочность скорлупы яиц / Л. Саприкин, В. Рябоконь / Птицеводство. 1987. - № 10. - C. 27-31.

4. Катаралашвілі A. Ш. Пути снижения боя и насечки яиц в промышленном птицеводстве / А. Ш. Катаралашвілі, Т. М. Околелова // Ефективне птахівництво. - 2006. - № 7. - C. $15-21$.

5. Ефективність детоксикуючих препаратів при вирощуванні курчат-бройлерів / М. Д. Засєкін, В.О. Жмайлов, Н. П. Пономаренко, Д. А. Засєкін // Сучасне птахівництво. 2008. - № 9 (70). - С. 2-5.

6. Цапко А. П. Пербаксан для обезврежевания поверхности скорлупы товарных яиц.

/ А. П. Цапко, И. Н. Щедров / Ветеринария. - 2006. - № 9. - С. 38-39.

7. Коиюмбас I. Я., Перспективи застосування гіпохлоритів у ветеринарній медицині. / І. Я. Коцюмбас, О. Б. Веліченко та ін. Монографія. Львів, ТзОВ, ВФ Афіша, 2009. - 312 с.

8. Доклінічні дослідження ветеринарних лікарських засобів / Монографія за ред. д.в.н., проф. Коцюмбаса І. Я. Львів: Тріада плюс, 2006. - 360 с.

9. Клінічні дослідження ветеринарних препаратів та кормових добавок. Монографія за ред. д.в.н., проф. Коцюмбаса І.Я. - Львів, ТОВ Видавничий дім «САМ», 2013. - 252 с.

\section{References}

1. Yaroshenko F. Suchasni svitovi tendentsii rozvytku ptakhivnytstva. K.: Novyi druk. 2003. 335 s. (in Ukrainian).

2. BesulinV.I., HuzhvaV.I., Kutsak S.M. ta inshi. Ptakhivnytstvo i tekhnolohiia vyrobnytstva yaiets ta miasa ptytsi. Za red. V.I. Besulina. Bila Tserkva, 2003. 448 s. (in Ukrainian). Russian).

3. Saprikin L., Rjabokon' V. Prochnost' skorlupy jaic. Pticevodstvo, 1987, №10.s.27-31 (in

4. Kataralashvili A.Sh., Okolelova T.M., Puty snyzhenyia boia y nasechky yayts v promushlennom ptytsevodstve. Efektyvne ptakhivnytstvo, 2006, №7. s.15-21 (in Ukrainian). 
5. Zasiekin M.D., Zhmailov V.O., Ponomarenko N.P., Zasiekin D.A. Efektyvnist detoksykuiuchykh preparativ pry vyroshchuvanni kurchat-broileriv. Suchasne ptakhivnytstvo, 2008, №9 (70). s. 2-5 (in Ukrainian).

6. Capko A.P., Shhedrov I.N. Perbaksan dlja obezvrezhevanija poverhnosti skorlupy tovarnyh jaic. Veterinarija, 2006, №9. s. 38-39 (in Russian).

7. Kotsiumbas I.Ia., Velichenko O.B. Perspektyvy zastosuvannia hipokhlorytiv u veterynarnii medytsyni. Monohrafiia. Lviv, TzOV, VF Afisha, 2009. 312 s.(in Ukrainian).

8. Doklinichni doslidzhennia veterynarnykh likarskykh zasobiv / Monohrafiia za red. d.v.n., prof. Kotsiumbasa I.Ia. Lviv, «Triada plius», 2006. 360 s.(in Ukrainian).

9. Klinichni doslidzhennia veterynarnykh preparativ ta kormovykh dobavok. Monohrafiia za red.d.v.n., prof. Kotsiumbasa I.Ia. - Lviv, TOV Vydavnychyi dim «SAM», 2013. 252 s.(in Ukrainian).

Рецензент - Б. В. Гутий, д. вет. н., професор, ЛНУВМБ імені С. З. Гжицького.

УДК 619:614. 48:636. 5

doi:10.36359/scivp.2019-20-2.43

\title{
ДОСЛІДЖЕННЯ ГОСТРОЇ ТА ХРОНІЧНОЇ ТОКСИЧНОСТІ ЗРАЗКІВ ГІНКГО БІЛОБА (GINKGO ВILOBA)
}

\author{
T. I. Фотіна, д-р вет. наук, професор, \\ Г. А. Фотіна, д-р вет. наук, професор, \\ С. М. Назаренко, канд. вет. наук, старший викладач, \\ A. I. Фотін, канд. вет. наук, дочент, \\ I. М. Коваленко, д-р біол. наук, професор, \\ Р. А. Ярощук, канд. с.-г. наук, доцент \\ Сумський національний аграрний університет, \\ вул. Герасима Кондратьєва, 160, м. Суми, 40021, Україна
}

У статті наведені результати гострої та хронічної токсичності зразків Гінкго Білоба. Встановлено, щзо при оцінці загального стану тварин через 30 хв. та 1 год після однократного введення екстракту у дозах 1000, 2500 та 5000 мг/кг відмічено зменшення рухливості як мишей, так і щурів, щуо минула на третю годину спостереження. Жодних інших ознак інтоксикації, зокрема з боку центральної та вегетативної нервової системи (бічне положення, зниження м'язового тонусу, порушення координації рухів, блефароптоз, гіперсалівачія тощо) не відмічено. Виходячи з результатів досліджень, екстракт Гінкго Білоба при підшкірному введенні білим мишам протягом 14 діб у терапевтичній дозі не спричиняв суттєвих змін загального стану, маси тіла, морфологічних та біохімічних показників крові.

Ключові слова: ГІНКГО БІЛОБА, ГОСТРА ТОКСИЧНІСТЬ, ФІЗІОЛОГІЧНИЙ СТАН, ХРОНІЧНА ТОКСИЧНІСТЬ, МОРФОЛОГІЧНІ ПОКАЗНИКИ КРОВІ, ЕКСТРАКТИ.

Гінкго білоба (Ginkgo biloba) - (гінкго дводольні, гінкго дволопатеве) - листяних дерев, відомих також під назвою адиантума, або кам'яного дерева, яке століттямі застосовується в 